\title{
Distribution tactics for success in turbulent versus stable environments: A complexity theory approach
}

\author{
Author: \\ Roger B. Mason ${ }^{1}$ \\ Affiliation: \\ ${ }^{1}$ Department of Marketing \\ and Retail Management \\ and Institute of Systems \\ Science, Durban University of \\ Technology, South Africa \\ Correspondence to: \\ Roger Mason \\ Email: \\ rogerm@dut.ac.za \\ Postal address: \\ PO Box 1334, Durban 4000, \\ South Africa \\ Dates: \\ Received: 19 July 2013 \\ Accepted: 02 Sept. 2013 \\ Published: 04 Nov. 2013 \\ How to cite this article: \\ Mason, R.B., 2013, \\ 'Distribution tactics for \\ success in turbulent versus \\ stable environments: A \\ complexity theory approach', \\ Journal of Transport and \\ Supply Chain Management \\ 7(1), Art. \#112, 9 pages. \\ http://dx.doi.org/10.4102/ \\ jtscm.v7i1.112
}

\section{Copyright:}

(C) 2013. The Authors. Licensee: AOSIS OpenJournals. This work is licensed under the Creative Commons Attribution License.

Read online:
This article proposes that the external environment influences the choice of distribution tactics. Since businesses and markets are complex adaptive systems, using complexity theory to understand such environments is necessary, but it has not been widely researched. A qualitative case method using in-depth interviews investigated four successful, versus less successful, companies in turbulent versus stable environments. The results tentatively confirmed that the more successful company, in a turbulent market, sees distribution activities as less important than other aspects of the marketing mix, but uses them to stabilise customer relationships and to maintain distribution processes. These findings can benefit marketers by emphasising a new way to consider place activities. How marketers can be assisted, and suggestions for further research, are provided.

\section{Introduction}

Business environments are 'chaotic and dynamic' (Fawcett \& Waller 2011). They have been changing, and will continue to change, due to: the accelerating pace of economic change; the explosion of innovative and new knowledge; increasing privatisation; the intensification of competitive pressures; the liberalisation of international trade; and the interdependence of global economies (Hooley \& Beracs 1997; Stapleton, Hanna \& Ross 2006). Globalisation means having to cope with different cultures, standards, regulatory and legal environments, and greater product variety at lower prices (Milgate 2001; Nilssen \& Gammelgaard 2012; Hashemi, Butcher \& Chhetri 2013). As a result, the environment has become more chaotic, fragmented, unpredictable, uncertain, risky, complex and turbulent (Lynch 1995; Stapleton et al. 2006; Nilsson 2006; Wang 2008; Malik, Niemeyer \& Ruwadi 2011; Hashemi et al. 2013). In developing countries, the increasing globalisation has exposed companies to volatility and unprotected business competition in which only the more competent survive (Malik et al. 2011). Developing countries, such as South Africa, provide global corporations with many opportunities. The South African business environment is facing increasing competition from these global corporations (Mason 2004). As a result there are more aggressive competitors chasing fewer customers.

This increasing global complexity and turbulence has resulted in increased volatility of demand and turbulence in distribution channels, especially for multinational companies (Kersten, Grussenmeyer \& Lammers 2012). In addition, marketing factors, such as the growth in scanner and retailer information systems, have given retailers more control than manufacturers, which has resulted in the growth of private label house brands that increase the supply chain complexity (Williams 1994; Roberts 2000).

Traditional planning and control systems cannot manage complexity (Windt \& Hülsmann 2007) and many supply chains are finding it difficult to cope with the increasing risk in today's turbulent and complex environments (Malik et al. 2011). Fawcett and Waller (2011) suggested that such problems need to be examined 'through new lenses'. A growing body of research is showing that complexity theory is useful in understanding and gaining new insights into logistics systems (Milgate 2001; Nilsson \& Waidringer 2004) and into the unpredictability in supply chains (Stapleton et al. 2006; Hashemi et al. 2013).

According to Maguire, Allen and McKelvey (2011), a complexity system is 'a "whole" made up of a large number of interacting "parts", or "agents", which are each governed by some rule or force'. The outcome of such systems is usually emergent phenomena brought about by 'upward causality'. These phenomena are not random or static - they are spontaneous, adapting to their environment, but are very difficult to predict, often because of small, seemingly inconsequential events. Complexity theory is the scientific study of complex systems and the emergence from, and self-organisation of, the phenomena arising from such systems. It has been shown to be applicable in systems such as biology, ecology, immune systems, economics and marketing. Sellitto et al. (2010) showed that complex behaviour occurs in supply chains. 
However, despite the growth in literature about complexity and complexity theory, there is still a lack of focus on complexity of distribution (Kersten et al. 2012) and very little focus on transportation as a complex system (Frazier \& Kockelman 2004), especially from a global perspective (Nilssen \& Gammelgaard 2012). There is also a lack of research into appropriate methods to cope with supply change complexity (Gerschberger et al. 2012), which is important since complexity and turbulence in supply chains are expected to continue to increase (Hashemi et al. 2013).

The purpose of this study was therefore to add to the logistics and complexity theory literature by investigating the types of logistics or distribution tactics suggested by the complexity theory literature for complex and turbulent environments versus those suggested for simple and stable environments. This was applied via a multiple-case study, exploratory approach in South Africa, which is a developing country with many industries experiencing extreme complexity and turbulence and growing competition from global competitors (Mason 2004).

\section{Literature review}

\section{Complexity theory}

Complexity theory is an overarching theory that includes a number of other theories, such as chaos theory, autopoeisis, dissipative structures, catastrophe theory and fractal geometry. A detailed explanation of the complexity theory is not possible in this paper, but a short discussion on the key components is given below. ${ }^{1}$

The underlying idea of complexity 'is that all things tend to self organise into systems' when simple rules are applied (Kelly \& Allison 1999). These systems can produce unexpected patterns or behaviours (Goldberg \& Markoczy 1998; Manuj \& Sahin 2011) because of non-linear feedback networks (Stacey 1996), the interconnection and interdependence of complex systems (Bar-Yam 2000) and because the system's parts interact and adapt to each other (Meade \& Rabelo 2004). Complex behaviour is orderly, yet full of surprise; it is apparently uncontrollable, yet not totally chaotic. The rules that generate this behaviour are not enforced by a 'manager', and cannot be predicted from any single part of the system and thus cannot be controlled (Wu \& Zhang 2007).

Several complexity concepts have relevance to business. The central concept is self-organisation; the process of order emerging from simple rules in a system, which a 'manager' does not control (Holbrook 2003), but which is due to the interaction between autonomous actors or agents in the system (Wilkinson \& Young 2013). Creative and innovative responses emerge despite the difficulty of 'managing' the system (Dolan, Garcia \& Auerbach 2003). This emergence, the second important concept, happens when the system changes, leading to disorder and prevention of the system from ossifying. Emergence happens at the edge-of-chaos, enabling new actions to emerge. New product development behaviour emerges from the operational level (McCarthy et al. 2006).

Third concept is feedback. Negative feedback damps change, pushing systems to equilibrium (Stacey 1995). Positive feedback amplifies small changes, pushing systems towards chaos (Doherty \& Delener 2001). Together, positive and negative feedback balance the system at the 'edge-of-chaos', which is the best position for turbulent environments (Doherty \& Delener 2001). Tarokh, Dabiri, Shokouhi and Shafiei (2011) showed how inventory management can produce selfreinforcing positive or negative feedback loops.

The fourth concept is sensitive dependence on initial conditions (Briggs \& Peat 1999). In stable systems, small changes have small effects, but in complex or turbulent systems small changes can grow exponentially, making long-term prediction impossible (Doherty \& Delener 2001; Holbrook 2003; Wu \& Zhang 2007). This phenomenon, also known as the 'butterfly effect', is similar to the 'bullwhip effect' in supply chains (Badillo-Pina, Tejeida-Padilla \& MoralesMatamoros 2012), which is typical of over-or under-reacting in dynamic environments (Wilkinson \& Young 2013). Small nudges, at the correct time, can lead to major changes (Wheatley 1996). Patterns and clues indicate which changes to 'nudge' (Morrison \& Quella 1999) and when to nudge them (Gladwell 2000). These patterns are known as attractors, which is the fifth concept. The edge-of-chaos attractor, known as a 'strange attractor', reflects the area where maximum creativity and innovation happens (Lewin 1992). A unique feature of the strange attractor is that it stays within certain boundaries (Holbrook 2003). How the system will develop cannot be predicted, but it will not go outside its attractor (Doherty \& Delener 2001). Thus, the attractor allows change whilst maintaining some order.

\section{Supply chains as complex adaptive systems}

Supply chains and distribution systems have been shown to be dynamical systems with islands of stability and predictable patterns. As with most dynamical systems, they reflect sensitivity to initial conditions and cannot be accurately predicted, with the resultant uncertainty leading to increased costs (Rasmusen \& Mosekilde 1988; Levy 1994; Wilding 1998; Holmstrom \& Hameri 1999; Ranjan, Kumara, Surana, Manikonda, Greaves \& Peng 2002; Sellitto et al. 2010; Hashemi et al. 2013). Supply chain complexity influences delivery performance (Milgate 2001) and even stabilising actions can increase uncertainty. Small differences in demand forecasting and feedback up the supply chain from the retail level can result in inventories decreasing and back orders growing, which result in over-compensation and excessive stocks - the bullwhip effect (Stacey 1996; Stapleton et al. 2006). Clearly, making any changes in a supply chain should be done with considerable care. For example, product proliferation and excessive promotional deals can lead to chaotic situations in distribution (Schiller, Burns \& Miller 1996), as can the use of inappropriate channel information. Using sales to the next 
level in the channel as input information can cause inventory levels to fluctuate significantly, between heavily overstocked, with resultant additional carrying costs throughout the channel, to under stocked, or out of stock, resulting in lost sales, overtime production, and faster transport costs, which leads to reduced profitability (Priesmeyer 1992). Even the number of members in the distribution network can lead to chaotic behaviour in the system (Tarokh et al. 2011).

\section{Traditional methods of managing the place tactics}

The place, or distribution, component of the marketing mix is traditionally one of the most conservatively handled marketing tactics, with minimal change taking place and a mechanistic and top-down approach traditionally being adopted (Nilsson et al. 2004). According to Nilson (1995), distribution and availability are two of the main stabilising dimensions of the marketing mix, because by controlling the link between supplier and customer, the supplier reduces the customer's ability to change suppliers, thereby making the market more stable. Kersten et al. (2012) referred to these as regulating strategies. This also applies similarly to backward integration by retailers and to forward integration by manufacturers, which reduce the uncertainty of whether the retailer will stock the manufacturer's product or not. This stabilises the environment.

The traditional approach to handling uncertainty in distribution also involves increasing safety stock, providing a broader range of products, lengthening lead times or improving distribution capabilities (Narus \& Anderson 1996; Milgate 2001), thus avoiding late deliveries, poor quality and unforeseen demand. Planning provides a good, and maybe even an optimum, solution in a stable environment, but in turbulent environments where the past is not repeating itself, planning based on the past can be dangerous (Johnston \& Betts 1996).

The place component is becoming less important and success can no longer be achieved by concentrating on improving the firm's distribution activities alone (Wilding 1998; Tapscott 2000). Traditional linear optimisation of supply chains is not adequate for modern dynamic systems. Poor communication can break the link between end-product demand and the manufacturing process, as happens when channel members operate in transactional, rather than relationship, mode (Holmstrom et al. 1999). Success in dynamical systems comes from the interrelationship of the performance of the company and its suppliers and customers. Supply chains are so complex that it is not possible for individual managers or buyers to take optimal decisions, as they are knowledgeable about only a very small proportion of the chain. Therefore, their decisions can have unpredictable effects up and down the supply chain. The traditional, transaction approach of a firm managing its place function independently is thus inadequate in a complex, rapidly- changing environment (Whiting 2001).

This brief discussion shows that the traditional approach of planning and control, and the use of buffer stocks to manage the place component, still appears relevant in a simple and stable environment, but is not necessarily the most effective approach in a turbulent environment. Therefore the following propositions are suggested:

Proposition 1: in a simple or stable industry, a more successful company uses distribution tactics in a stabilising way.

Proposition 2: in a simple or stable environment, a less successful company uses distribution tactics in a destabilising way.

\section{Complexity methods of managing place tactics}

Since increased planning and control is only superior in a predictable environment (Johnston \& Betts 2000), and since the non-linear distribution channels can be stable, periodically oscillating or chaotic (Priesmeyer 1992), alternative methods of managing the place component are needed. Each channel member can maintain, increase or dampen system oscillations by their actions, and the more members there are in the channel, the more complex the system becomes. If each member of the chain then tries to optimise its own performance, minor ordering differences or disturbances may be amplified up the chain, resulting in large, unpredictable disturbances. Forrester (in Stacey 1996) stressed that the solution is to treat the whole supply chain as a single system, aiming for optimisation of the system rather than the individual elements. Such a holistic system (Kersten et al. 2012) also has the benefit of minimising the possibility of the bullwhip effect (Geary, Disney \& Towill 2006). A complexity approach to managing the whole system would include:

- Using correct supply chain information - when enduser or consumer-demand information (generated at the point-of-sale) is used to replenish inventory throughout the channel, much more consistent inventory levels result. Damping of fluctuations leads to reduction of safety stocks and minimisation of stock outs, resulting in reduced supply chain costs and overall improvement of channel profitability (Priesmeyer 1992; Wilding 1998; Milgate 2001; Stapleton et al. 2006). This is supported by De Leeuw, Grotenhuis and Van Goor (2013), who found that exchanging information and communication were key coping mechanisms, and by Chien-Yuan and Jinsheng's (2011) finding that the use of radio-frequency identification (RFID) technology can diminish chaos in a supply chain.

- Accepting the uncertainty and adopting short term, or reactive, managerial actions within the prediction horizon. This approach is simpler, can respond more quickly to opportunities, reduces operating costs and increases the value of the system (Levy, 1994; Wilding 1998; Johnston et al. 2000). De Leeuw et al. (2013) supported this and found that flexibility is a key means of coping with complexity.

- Treating the supply chain as a complex adaptive system uses a few simple rules to manage the system. For example, Southwest Airlines simulated their cargo operation by using a few simple rules and saved millions of dollars 
by not transferring packages to the most direct flights a decision that was counter-intuitive (Whiting 2001).

- Shifting competition from 'between firms' to 'between supply chains' leads to a growth in alliances and collaborations (Stapleton et al. 2006). Partnerships and strategic alliances in supply chains leads to a blurring between members of the supply chain with their roles overlapping and co-location taking place. This improves knowledge of customer needs, reduces stock holdings and speeds up the delivery cycle (Glazer 1991; Mohr 2001). This sees a shift away from rivalry towards partnerships and extended co-operation (Milgate 2001) and outsourcing to one or two suppliers (De Leeuw et al. 2013), with such collaborative relationships reducing supply chain complexity and turbulence (Manuj \& Sahin 2011).

- Despite the above, buffer inventories, reserve equipment or flexible staffing are often used to stabilise the chaosinspired uncertainties in the demand in the supply chain. This increases the flexibility of the system (Manuj \& Sahin 2011). These buffers allow the system to operate in a chaotic environment as they absorb or dampen unpredictable fluctuations (Phillips \& Kim 1996). In fact, De Leeuw et al. (2013) found inventory to be the main coping mechanism for complexity in supply chains.

Based on the above approach, the concept of 'adaptive channels' has been suggested because of the increasing dynamics of business and increasing competition, especially from global competitors who use unconventional methods because of their exclusion from the traditional channels (Narus et al. 1996). The 'adaptive channels' method involves cooperative arrangements, strategic alliances and partnerships between channel members and other suppliers, using shared information systems and integrated logistics systems. The network of capabilities in the channel enables it to be more flexible and responsive by having all the skills and inventories to satisfy the standard and emergency needs of customers. Instead of trying to cope with the chaos of unanticipated emergency demands by increasing inventory levels, the system copes with it by sharing the inventory load and by very quickly responding through integrated computer systems and express delivery suppliers. In other words, the chaos is coped with through the larger system, rather than each agent in the system trying to cope with its own locally generated problem through traditional planning and control (Wang 2008). This is consistent with managing supply chains as emergent and self-organising phenomena (Nilsson et al. 2004). In fact it might end up with increased supply chain complexity (De Leeuw et al. 2013).

Based on this analysis, two more propositions are suggested:

Proposition 3: in a complex or turbulent industry, a more successful company uses distribution tactics in a destabilising way.

Proposition 4: in a complex or turbulent industry, a less successful company uses distribution tactics in a stabilising way.

In summary, the literature has suggested that the following are the key place tactics that can be used in a stabilising or destabilising way, and that are important in, and can vary according to the nature of the environment: use of intermediary; partnership or alliances; physical distribution; stock levels; and stock replenishment. The literature also suggests that more successful companies in complex and turbulent environments are more likely to use the place tactics in a destabilising way, whilst more stabilising ways of using these tactics are more likely to be typical of successful firms in simple and stable environments. The research problem is thus whether this applies in practice, and moreover, whether it applies in a developing country like South Africa. Therefore, the research objective of this study is to assess whether the proposals developed from the literature review can be accepted in the South African environment.

\section{Research strategy Research approach}

The objective of the study was to investigate the types of distribution tactics adopted in turbulent or complex industries versus those adopted in stable or simple industries and their relevance to success in these industries. In other words, is there a relationship between type of distribution tactics and success in a turbulent environment? To answer this question, the findings of the literature review, viewed through the complexity lens, were summarised to develop models of what place tactics could be expected of more successful and less successful companies in complex or turbulent and simple or stable markets (Mason \& Staude 2009). These models are presented in Tables 2 and Table 3 respectively. Also based on the literature, the four propositions mentioned above were developed to enable the empirical findings to be compared against the models.

Due to the paucity of complexity-oriented research in this field, a qualitative exploratory approach, namely the case study, was chosen (Gerschberger et al. 2012; Wilkinson \& Young 2013). The research was conducted in South Africa, where most components of the external environment are turbulent, which make it a good 'laboratory' (Morris et al. 1996; Joubert 1998).

\section{Respondents}

Two companies, each in a simple or stable industry and a complex or turbulent industry, were selected using maximal variation sampling. The sample was selected through a twostage process:

- First, the most complex or turbulent and simple or stable industries were selected via a questionnaire posted to experts who were industry analysts and management consultants. The results highlighted information technology as being the most complex or turbulent, and packaging as the most simple or stable.

- Within each industry, more successful and less successful companies were chosen using a Delphi process, with panels of industry experts who were consultants, journalists and buyers. They were asked to subjectively or qualitatively consider 'success' in terms of the companies' 
performance over the previous three to five year period. The more successful firms being those that had achieved consistent growth in sales, profits and assets, that had increased market share, or that had adapted well to their changing environment. The less successful firms were those that had performed poorly on these factors. To maintain anonymity, artificial names were developed for the companies $-\mathrm{C}$ was used to indicate an information technology (computer) company and $\mathrm{P}$ indicated a packaging company, whilst A was used for a more successful company and B for a less successful company. The experts thus nominated CA as more successful and $\mathrm{CB}$ as less successful in the information technology industry, and PA as more successful and PB as less successful in the packaging industry. Table 1 provides a profile of the four companies.

\section{Method of data gathering}

Yin (2003) suggested certain protocols to ensure reliability of data collection. Thus, initial contact was made with either the Chief Executive Offices or senior marketing managers and permission to collect data from their companies was obtained. Names and titles of employees to be interviewed were agreed and appointments were made to interview these respondents in their offices or place of work. Using an interview guide developed from the literature review, data were collected from 31 directors, managers and staff of the four sample companies, who were what Morse (in Flick 1998:70) referred to as 'good informants'. Data were collected via semi-structured depth interviews (Oka \& Shaw 2000), which were audiotape recorded. Interviews lasted between $30 \mathrm{~min}$ and $1 \mathrm{~h}$. The interviewer also took written notes during the interviews and company documents were obtained and manually analysed (for example, annual reports, brochures, web pages, advertisements, minutes and manuals). This provided the multiple methods and evidence sources suggested by Keen and Packwood (1999) for case research, which provide both an 'etic' (outsider) and 'emic' (insider) perspective (Denzin \& Lincoln 1994). To obtain the companies' co-operation, anonymity was necessary, which is why the artificial names of CA, CB, PA and PB were used.

\section{Treatment of the data}

Analysis was via thematic coding using NVIVO software (QSR International, Australia) to deconstruct the individual transcriptions and then to reconstruct the resultant extracts into common themes (Lee 1999). Findings were categorised according to the two perspectives being studied (stable or turbulent and more or less successful). Manual content analysis summarised the field notes and documents for comparison with the research propositions. These analyses were then used to compare the two companies in each industry against each other and against the proposals, and to compare the companies similar in success to each other and against the proposals. The pattern matching logic suggested by Yin (2003) was used for these comparisons.

'Method-appropriate criteria' and multiple data collection methods validated the procedures, increasing rigor and trustworthiness, namely: (1) the data triangulation (multiple interviewees, documentation and field notes); (2) methodological triangulation (qualitative interviews with some quantitative content analysis); (3) prolonged engagement (multiple interviews and minimum of three days spent in each firm); and (4) an audit trail (all data collected was kept on CD) (Flick 1998). Using multiple data sources increased construct validity. Internal validity was increased by comparison and pattern matching across the cases. External validity was increased by using cross-case analysis of multiple cases (thereby allowing some generalisation). Reliability was increased by using a data collection protocol and by keeping a database of the empirical data and a chain of evidence (Yin 2003). This method adhered to the ten design considerations of Lincoln and Guba (in Rudestam \& Newton 1992) and thus met the criteria for a high quality, rigorous and trustworthy study.

\section{Findings}

Distribution is a major stabilising tactic (Nilson 1995), so understanding its importance in the companies' marketing tactics is important. The findings relative to the turbulent environment and the stable environment are discussed, specifically, the use of channel intermediaries, inventories and physical distribution.

\section{Turbulent and complex environment}

Based on the empirical study, a summary was created and mapped against Model 1, which is mentioned previously and presented in Table 2. It shows that CA's place tactics match the Model very closely, as proposed in Proposition 3. A perfect match would have been shown by six 'yes' matches (equal to $100 \%$ ) in the fourth column, which summarises CA's comparisons. They achieved three 'yes' matches and three 'partial' matches and zero 'non' matches, giving a total score of $75 \%$.

It was expected that $\mathrm{CB}$ would not match Model 1 very closely, as proposed in Proposition 4. A perfect mismatch would be shown by six 'non' matches (equal to $0.0 \%$ ) in

TABLE 1: Profile of sample companies.

\begin{tabular}{ll}
\hline Company & Characteristics \\
\hline $\mathrm{CA}$ & Large company listed on stock exchange, operates nationally, regionally and internationally. Emphasis is on hardware and software. \\
$\mathrm{CB}$ & Medium to large company listed on stock exchange, operates nationally, regionally and to a limited extent, internationally. Emphasis is on software. \\
$\mathrm{PA}$ & Medium sized subsidiary of a packaging group, trading nationally - focusing on flexible packaging, especially for the food and beverage industry. \\
$\mathrm{PB}$ & Long established, family business, trading nationally - focusing on a wide range of packaging applications, especially pharmaceutical. \\
\hline $\mathrm{CA}$, more successful company in information technology (computer) industry; CB, less successful company in information technology (computer) industry; PA, more successful company in packaging \\
industry; PB, less successful company in packaging industry.
\end{tabular}


the last column, which summarises CB's comparisons. This indicates that $\mathrm{CB}^{\prime}$ 's place tactics partially match the Model, with a summed score of $58.3 \%$. There were three 'non' matches, one 'partial' match and one 'yes' match.

\section{Stable and simple environment}

Based on the empirical study, a summary was created and mapped against Model 2, which is mentioned previously and presented in Table 3. It shows that PA's place tactics did not match Model 2 very closely, the opposite of what was proposed in Proposition 1. A perfect match would have been shown by six 'yes' matches (equal to 100.0\%) in the fourth column, which summarises PA's comparisons. They achieved two 'yes' matches and one 'partial' match and three 'non' matches, giving a summed score of $41.7 \%$.

It was proposed in Proposition 2 that PB would not match Model 2 very closely. A perfect mismatch would be shown by six 'non' matches (equal to $0.0 \%$ ) in the last column, which summarises PB's comparisons. This indicates that PB's place tactics partially match the Model, with a summed score of $41.7 \%$. There were two 'non' matches, three 'partial' matches and one 'yes' match.

\section{Discussion}

\section{Turbulent and complex environment}

In terms of distribution channels, both, companies mostly deal directly with the users of their products - CB does not make use of any intermediaries, but CA does, to a limited extent, use intermediaries for global markets. CA also deploys its services into international regions and leverage skills by using specialists from different regions or products, whereas CB's international business is handled through the use of technology.

Both companies make use of partnerships and strategic alliances, but for CB this is a recent innovation, whereas for $\mathrm{CA}$ there are long standing alliances and it is more prepared to partner with competitors if it is in their interests.

Differences between the two companies exist in the area of physical distribution, because CA deals, to a considerable extent, in computer hardware, whereas CB does not. CA does not carry stock due to the rapidly changing nature of its industry, so physical distribution is generally less important. However, not carrying stock means that it has to manage the supply of materials very carefully, so logistics is critical as mistakes can result in lost sales. For CB, physical distribution is not seen as important because it does not sell 'products'. However, CB is aware of the importance of distribution of its services, which involves deploying staff geographically.

The nature of the two companies' business seems to influence their attitudes towards distribution. CA's heavier emphasis on business outside South Africa and the fact that it sells hardware means that it places more emphasis on intermediaries and logistics than $\mathrm{CB}$, which predominantly sells software and systems. CB's emphasis on customised software leads to problems in the physical distribution of its main resource, which is, people. Taking this factor into account, it appears as if 'place' does not account for much difference between the two companies. Furthermore, from the relatively low-key approach to distribution, it appears as if both companies consider 'place' to be less important than the other components of the marketing mix.

TABLE 2: Complex or turbulent environment.

\begin{tabular}{|c|c|c|c|c|c|}
\hline Variable & Model 1 & Company CA & Match & Company CB & Match \\
\hline Use of intermediaries & Reduce intermediaries. Deal more with end users. & Mostly direct with users. Few intermediaries. & Yes & No use of intermediaries. & Yes \\
\hline Partnership or alliances & $\begin{array}{l}\text { Partnerships and strategic alliances used. } \\
\text { Boundaries and roles blurred. Staff on customer } \\
\text { or supplier site. Shared information. }\end{array}$ & $\begin{array}{l}\text { Partnership and strategic alliance } \\
\text { collaboration used extensively, also with } \\
\text { competitors. }\end{array}$ & Yes & $\begin{array}{l}\text { Few partnerships or alliances, } \\
\text { although seen as becoming } \\
\text { important. }\end{array}$ & No \\
\hline Physical distribution & $\begin{array}{l}\text { Quick delivery to reduce need for inventory- } \\
\text { often same-day delivery. }\end{array}$ & $\begin{array}{l}\text { No buffer stocks - quick delivery and just-in- } \\
\text { time logistics important. }\end{array}$ & Yes & $\begin{array}{l}\text { Geographic spread of staff to jobs } \\
\text { difficult, so important. }\end{array}$ & Partial \\
\hline Stock levels & $\begin{array}{l}\text { Stock shared in chain. Quick response, integrated } \\
\text { computer systems. }\end{array}$ & $\begin{array}{l}\text { No stocks - order for specific job, so manage } \\
\text { supply carefully. }\end{array}$ & Partial & $\begin{array}{l}\text { No stock carried as deal in } \\
\text { services. }\end{array}$ & No \\
\hline Importance of place & $\begin{array}{l}\text { Important, but is a 'given'. Overall system copes } \\
\text { with environmental turbulence. }\end{array}$ & $\begin{array}{l}\text { Important for material supply, but not } \\
\text { overall, as is 'service' business. }\end{array}$ & Partial & $\begin{array}{l}\text { Little importance placed on } \\
\text { distribution. }\end{array}$ & Partial \\
\hline
\end{tabular}

TABLE 3: Simple or stable environment.

\begin{tabular}{|c|c|c|c|c|c|}
\hline Variable & Model 2 & Company PA & Match & Company PB & Match \\
\hline Use of intermediaries & $\begin{array}{l}\text { Distribution done via traditional channel } \\
\text { members or intermediaries. }\end{array}$ & $\begin{array}{l}\text { Not used except for transport and minor } \\
\text { commission agents. }\end{array}$ & No & $\begin{array}{l}\text { Not used. Only transport and } \\
\text { minor commission agents. }\end{array}$ & No \\
\hline Partnership or alliances & $\begin{array}{l}\text { Arms length relationships - not integrated } \\
\text { partnerships. }\end{array}$ & $\begin{array}{l}\text { Only a few informal partnerships and co- } \\
\text { operation. }\end{array}$ & Yes & $\begin{array}{l}\text { Only a few informal partnerships } \\
\text { and co-operation. }\end{array}$ & Yes \\
\hline Physical distribution & $\begin{array}{l}\text { Delivery important, but within traditional lead } \\
\text { times. }\end{array}$ & $\begin{array}{l}\text { Important, but only to get product to } \\
\text { customer. }\end{array}$ & Yes & $\begin{array}{l}\text { Important, to achieve competitive } \\
\text { parity or superiority. }\end{array}$ & Partial \\
\hline Stock levels & $\begin{array}{l}\text { Carry own buffer stocks. Responsible for levels to } \\
\text { achieve supply rates. }\end{array}$ & $\begin{array}{l}\text { Keep stocks low. Mostly make to order. } \\
\text { Suppliers keep stock. }\end{array}$ & No & $\begin{array}{l}\text { Kept low, by suppliers. Stocks kept } \\
\text { for a few, special customers. }\end{array}$ & Partial \\
\hline Stock replenishment & $\begin{array}{l}\text { Long-term forecasts to lower uncertainty. Stocks } \\
\text { based on customer demand. Buffer inventory to } \\
\text { cater for uncertainty. }\end{array}$ & $\begin{array}{l}\text { Planned according to customer stock levels } \\
\text { and orders. Fairly short-term. }\end{array}$ & No & $\begin{array}{l}\text { Planning based on customer stock } \\
\text { levels - rather reactive. Fairly } \\
\text { short-term. }\end{array}$ & No \\
\hline Importance of place & Seen as critical to success. & $\begin{array}{l}\text { Important, is necessity, but not seen as a } \\
\text { tactical weapon. }\end{array}$ & Partial & $\begin{array}{l}\text { Important, but not a tactical } \\
\text { weapon. }\end{array}$ & Partial \\
\hline
\end{tabular}


These findings are generally what would have been expected for a more successful company in a turbulent and complex market (CA), and so Proposition 3 can be accepted, namely that a more successful firm in a complex or turbulent market tends to use destabilising place tactics.

Regarding the less successful company (CB), almost the opposite of what was anticipated was found. Therefore, Proposition 4 could only be partially accepted, namely, the less successful firm tends to use a mix of stabilising and destabilising tactics.

The reason for this anomaly seems to be that CB has not yet had to face distribution problems as it has been operating mainly in a domestic niche market, both in terms of a specific industry, and in terms of a geographic region, whereas CA involves physical distribution of products in both the domestic and global markets.

\section{Stable and simple environment}

Although both companies stress the importance of distribution, it appears to be important in the sense that it is a given - a necessary, basic foundation for their operations, rather than a tactical weapon to be manipulated. They both use direct distribution channels, selling directly to the packaging users. Generally speaking, intermediaries are not used, with the exception of a few commission sales agents and a transport company. Neither company uses partnerships or strategic alliances to further its distribution objectives. They do, however, have some 'informal partnerships' and cooperation with some suppliers, although these cannot be termed strategic alliances.

Both companies emphasise the importance of physical distribution for the success of their operations, because of the criticality of on-time delivery.

Both companies do carry small quantities of stock of both raw materials and finished goods, but the stock levels are kept to a minimum. They generally produce to order, or only keep stocks for selected, preferred or larger customers. Raw material stocks are also kept to a minimum by encouraging suppliers to keep back-up stocks for them. Both companies, rather than producing as and when necessary or carrying large buffer stocks do stock replenishment on a planned basis for customers. PA's inventory planned replenishment is indicated by its 'stock schedule system', whereas PB's stock replenishment is more reactive, at the request of the customer.

The distribution activities of both companies were very similar. No significant differences between the two companies were found. As a generalisation, it appears as if both companies see distribution as a fundamental activity that has to be done well, regardless of the environment or any other tactical activities. As such, the successful company in the stable and simple environment (PA) places sufficient attention on distribution to ensure that its stabilising influence supports its other activities. On the other hand, the less successful company (PB), which was expected to downplay the importance of distribution, does place some importance on the distribution function, seeing it as fundamentally important.

For both companies, the distribution tactics were generally as expected, although for company $\mathrm{PB}$, the lack of alliances and the planned stock replenishment was not as expected. Both Proposition 1 and Proposition 2 can only be partially accepted, implying that both companies use a mix of stabilising and destabilising place tactics.

In summary, the following are the conclusions drawn from the findings regarding each proposition:

Proposition 1: in a simple or stable industry, a more successful company uses stabilising distribution tactics: partially accepted as PA uses a mix of stabilising and destabilising place tactics.

Proposition 2: in a simple or stable environment, a less successful company uses destabilising distribution tactics: partially accepted as PB uses a mix of stabilising and destabilising place tactics.

Proposition 3: in a complex or turbulent industry, a more successful company uses destabilising distribution tactics: accepted as CA tends to use destabilising place tactics.

Proposition 4: in a complex or turbulent industry, a less successful company uses stabilising distribution tactics: partially accepted as CB tends to use a mix of stabilising and destabilising place tactics.

\section{Implications for marketing}

The place component generally should not be treated just as a short-term tactic to be used aggressively. It forms the foundation through which the rest of the marketing mix is implemented. At the same time, it cannot just be seen as a means to buffer demand fluctuations and supply uncertainties. The overall system must be designed to cope with complexity and turbulence. The entire supply chain must be treated as a single system, and if change is required it must be implemented through the entire supply chain. The use of traditional arms-length intermediaries should be minimised and more use should be made of close partnerships and strategic alliances, with blurring of boundaries between the organisations being encouraged. The use of such partnerships and alliances increases system flexibility and increases the system's knowledge of the environment. Regarding inventory and physical distribution, the entire supply chain should share the inventory load, with stock replenishment being based on end-user demand rather than the demand from the immediate customer. Emphasis should be on quick response and short-term management of the system, rather than on building buffers to cope with the uncertainty. This quick response includes using the fastest delivery method possible. 


\section{Conclusions}

\section{Summary}

A general finding of the study is that distribution was seen by the respondent companies as a basis of the business, a 'given'. All of the firms saw it as 'important', but none used it as a significant, aggressive tactical weapon. Although the study's findings did not strongly support the propositions, there is some support for the belief that firms, in the preparation of their marketing mixes, consider the stabilising and destabilising nature of place tactics. CA, the more successful firm in the complex or turbulent environment, clearly uses place tactics in a destabilising aggressive way, whilst all the other companies use place tactics in both stabilising and destabilising ways - destabilising, for example, to increase competitiveness through quick deliveries, and stabilising, for example, to help strengthen customer relationships.

The net result of these findings is that place tactics should not just be seen as the basic stabilising foundation upon which other tactics are built. Seeing place tactics as just increasing safety stock, lengthened lead times or improving distribution capabilities (Narus \& Anderson 1996; Milgate, 2001), or as Kersten et al. (2012) puts it, using regulating strategies, is no longer sufficient. In turbulent environments, supply chains should be treated as emergent and self-organising phenomena (Nilsson et al. 2004), and therefore the 'adaptive channels' method involving co-operative arrangements, strategic alliances and partnerships, shared information systems and integrated logistics systems throughout the whole supply chain should be used, as suggested by Narus et al. (1996).

\section{Limitations of study}

Since this was a small sample, exploratory study, it is subject to the limitations of small sample studies. The findings are not necessarily representative of all companies in the sampled industries, nor are they necessarily representative of similar environments. The study has, however, provided better understanding of these relationships. There was no intention to try to extrapolate results to all companies or markets. If extrapolation of the results to other industries is done, it should be done with caution. One of the strengths of the study, the use of maximal variation sampling, is also a weakness. This is because the choice of only two industries and two companies each makes it difficult to draw conclusions about other industries and other companies.

\section{Recommendations for further research}

Although this research study has cast some new light on place tactics by viewing them from a chaos and complexity perspective, there is still much to be learnt about the use of place tactics in turbulent environments. It is further believed that some of the problems identified in this paper can be resolved by further research using a chaos and complexity approach. Resolution of the anomalies and difficulties mentioned in the Limitations, and expansion of knowledge of place tactics, could be achieved through research in a wider range of companies and in different industries. A larger, quantitative study may better measure the effects of the place tactics discussed.

\section{Acknowledgements}

I would like to thank the anonymous reviewers for this journal, and the reviewers and delegates of the 15th Global Business and Technology Association (GBATA), Helsinki conference, at which an earlier version of this article was presented. Their critiques, comments and suggestions have added considerably to the quality of this article.

\section{Competing interests}

The author declares that he has no financial or personal relationship(s) that may have inappropriately influenced him in writing this article.

\section{References}

Badillo-Pina, I., Tejeida-Padilla, R. \& Morales-Matamoros, O., 2012, 'A systems science perspective for sypply chain management', Proceedings of the 56th annual meeting of the ISSS, San Jose, CA, USA.

Bar-Yam, Y., 2000, Guide to Complex Systems, New England Complex Systems Institute, viewed 29 June 2000, from http://www.necsi.org/guide

Briggs, J. \& Peat, F.D., 1999, Seven Life Lessons of Chaos: Timeless Wisdom from the Science of Change, Harper Collins, New York.

Chien-Yuan, S. \& Jinsheng, R., 2011, 'Investigating the impacts of RFID application on supply chain dynamics with chaos theory', WSEAS transactions on information science and applications 8(1), 1-17.

De Leeuw, S., Grotenhuis, R. \& van Goor, Ad.R., 2013, 'Assessing complexity of supply chains: Evidence from wholesalers', International Journal of Operations and Production Management 33(8), 960-980. http://dx.doi.org/10.1108/IJOPM-07-2012-0258

Denzin, N.K. \& Lincoln, Y.S., 1994, Handbook of Qualitative Research, Sage, Thousand Oaks. PMid:7600288

Doherty, N. \& Delener, N., 2001, 'Chaos Theory: Marketing and Management Implications', Journal of Marketing Theory and Practice 9(4), 66-75.

Dolan, S.L., Garcia, S. \& Auerbach, A., 2003, 'Understanding and Managing Chaos in Organisations', International Journal of Management 20(1), 23-35.

Fawcett, S.E. \& Waller, M.A., 2011, 'Making sense out of chaos: Why theory is relevant to supply chain research', Journal of Business Logistics 32(1), 1-5. http://dx.doi. org/10.1111/j.2158-1592.2011.01000.x

Flick, U., 1998, An Introduction to Qualitative Research, Sage, London.

Frazier, C. \& Kockelman, K.M., 2004, 'Chaos Theory and Transportation Systems: An Instructive Example', Conference proceedings of 83rd Annual Meeting of the Transportation Research Board, Washington, DC, USA, viewed 14 January the Transportation Research Board, Washington, DC, USA, viewed 14 January
2011, from http://pdfcast.org/pdf/chaos-theory-and-transportation-systems-an2011, from http://p
instructive-example

Geary, S., Disney, S.M. \& Towill, D.R., 2006, 'On bullwhip in supply chains - historical review, present practice and expected future impact', International Journal of
Production Economics 101, 2-18. http://dx.doi.org/10.1016/j.ijpe.2005.05.009

Gerschberger, M., Engelhardt-Nowitzki, C., Kummer, S. \& Staberhofer, F., 2012, 'A model to determine complexity in supply networks', Journal of Manufacturing Technology Management 23(8), 1015-1037. http://dx.doi.org/10.1108/17410381211276853

Gladwell, M., 2000, The Tipping Point: How little things can make a big difference, Abacus, London.

Glazer, R., 1991, 'Marketing in an Information-Intensive Environment: Strategic Implications of Knowledge as an Asset', Journal of Marketing 55(4), 1-19. http:// dx.doi.org/10.2307/1251953

Goldberg, J. \& Markoczy, L., 1998, Complex Rhetoric and Simple Games, Cranfield University, Cranfield, Bedfordshire, United Kingdom, viewed 02 February 1999, from www.Cranfield.ac.za/public/cc/cc047/papers/complex/html/complex.htm

Hashemi, A., Butcher, T. \& Chhetri, P., 2013, 'A modelling framework for the analysis of supply chain complexity using product design and demand characteristics', International Journal of Engineering, Science and Technology 5(2), 150-164.

Holbrook, M.B., 2003, 'Adventures in Complexity: Dynamic Open Complex Adaptive Systems, Butterfly Effects, Self-Organizing Order, Co-evolution, the Ecological Perspective, Fitness Landscapes, Market Spaces, Emergent Beauty at the Edge of Chaos, and All That Jazz', Academy of Marketing Science Review 6, viewed 02 Frebruary 2006, from http://www.amsreview.org/articles/holbrook06-2003.pdf

Holmstrom, J. \& Hameri, A-P., 1999, 'The Dynamics of Consumer Response: A quest for the attractors of supply chain demand', International Journal of Operations and Production Management 19(10), 993-1009. http://dx.doi.org/10.1108/ 01443579910287037 
Hooley, G. \& Beracs, J., 1997, 'Marketing Strategies for the 21st Century: Lessons from the top Hungarian companies', Journal of Strategic Marketing 5, 143-165. http:// the top Hungarian companies', Journal
dx.doi.org/10.1080/096525497346776

Johnston, R.B. \& Betts, J.M., 1996, 'A Complex Systems Simulation of Planning versus Reacting for Inventory Replenishment', Complexity International 3, viewed 18 November 1997, from http://www.csu.edu.au/ci/vol3/typeset1/typeset1.html.

Johnston, R.B. \& Betts, J.M., 2000, 'A complex-systems simulation approach to evaluating plan-based and reactive trading strategies', in W.A. Barnett, C. Chiarella, S. Keen, R. Marks, and H. Schnabl, Commerce, Complexity, and Evolution: Topics in Economics, Finance, Marketing and Management, Proceedings of the Twelfth International Symposium in Economic Theory and Econometrics, Cambridge University Press, Cambridge, pp. 291-311.

Joubert, D., 1998, Competitive Firms Thrive on Instinct, Queillerie, Cape Town.

Keen, J. \& Packwood, T., 1999, Using case studies in health services and policy research, in C. Pope \& N. Mays, Qualitative Research in Health Care, 2nd edn., BMJ, London, viewed 23 August 2001, from http://www.bmjpg.com/qrhc/chapter6.htm

Kelly, S. \& Allison, M.A., 1999, The Complexity Advantage: How the Science of Complexity Can Help Your Business Achieve Peak Performance, BusinessWeek Books, New York.

Kersten, W., Grussenmeyer, R. \& Lammers, T., 2012, 'Current approaches in complexity management - practical and theoretical implications for distribution networks, Research in Logistics and Production 2(1), 55-68.

Lee, T.W., 1999, Using Qualitative Methods in Organizational Research, Sage, Thousand Oaks.

Levy, D., 1994, 'Chaos theory and strategy: Theory, application and manageria implications', Strategic Management Journal 15, 167-178. http://dx.doi.org/ 10.1002/smj.4250151011

Lewin, R., 1992, Complexity: Life at the edge of chaos, MacMillan, New York.

Lynch, J.E., 1995, 'Marketing and business process re-engineering', Journal of Marketing Practice: Applied Marketing Science 1(1), 45-53. http://dx.doi.org/10.1108/ EUM0000000003879

Maguire, S., Allen, P. \& McKelvey, B., (eds.), 2011, The SAGE Handbook of Complexity and Management, Sage, London.

Malik, Y., Niemeyer, A. \& Ruwadi, B., 2011, 'Building the supply chain of the future', McKinsey Quarterly, viewed 20 January 2011, from https://www.mckinseyquarterly. com/article_print.aspx?L2=1\&L3=26\&ar=2729.

Manuj, I. \& Sahin, F., 2011, 'A model of supply chain and supply chain decision-making complexity', International Journal of Physical Distribution and Logistics Management 41(5), 511-549. http://dx.doi.org/10.1108/09600031111138844

Mason, R.B., 2004, An investigation into how marketers cope with an environment of high complexity and turbulence, with special reference to the South African environment, Unpublished PhD thesis, Rhodes University, Grahamstown. http:// dx.doi.org/10.1108/02635570910930082

Mason, R.B. \& Staude, G., 2009, 'An exploration of marketing tactics for turbulent environments', Industrial Management and Data, Systems 109(2), 173-190.

McCarthy, I.P., Tsinopoulos, C., Allen, P.M. \& Rose-Anderssen, C., 2006, 'New Product Development as a Complex Adaptive System of Decisions', Journal of Product Innovation Management 23(5), 437-456. http://dx.doi.org/10.1111/j.1540 Innovation Managem
$5885.2006 .00215 . x$

Meade, P.T. \& Rabelo, L., 2004, 'The technology adoption life cycle attractor: Understanding the dynamics of high-tech markets', Technological Forecasting and Social Change the dynamics of high-tech markets', Technological Forecasting a
17, 667-684. http://dx.doi.org/10.1016/j.techfore.2004.01.008

Milgate, M., 2001, 'Supply chain complexity and delivery performance: An international exploratory study', Supply Chain Management: An International Journal 6(3), 106-118. http://dx.doi.org/10.1108/13598540110399110

Mohr, J., 2001, Marketing of High-Technology Products and Innovations, Prentice Hall, Upper Saddle River.

Morris, M.H., Marks, A.S., Allen, J.A., Peery, J.R. \& Newman, S., 1996, 'Modelling Ethical Attitudes and Behaviours Under Conditions of Environmental Turbulence: The Case of South Africa', Journal of Business Ethics 15, 1119-1130. http://dx.doi org/10.1007/BF00412052

Morrison, D.J. \& Quella, J.A., 1999, 'Pattern thinking: Cutting Through the Chaos', Marketing Management 8(4), 1-7.

Narus, J.A. \& Anderson, J.C., 1996, 'Rethinking Distribution: Adaptive Channels', Harvard Business Review, July-August, pp. 112-120.

Nilson, T.H., 1995, Chaos Marketing: How to win in a turbulent world, McGraw-Hill, London.

Nilsson, F. \& Waidringer, J., 2004, 'Logistics Management from a Complexity Perspective', The ICFAI Journal of Operations Management 3(2), 59-73.
Nilsson, F., 2006, 'Logistics management in practice - towards theories of complex logistics', The International Journal of Logistics Management 17(1), 38-54. http:// dx.doi.org/10.1108/09574090610663428

Nilsson, F.R. \& Gammelgaard, B., 2012, 'Moving beyond the Systems Approach in SCM and Logistics Research', International Journal of Physical Distribution and Logistics Management 42(8/9), 764-783. http://dx.doi.org/10.1108/09600031211269749

Oka, T. \& Shaw, I., 2000, Qualitative Research in Social Work, viewed 23 August 2001, from: http://pweb.sophia.ac.jp/ t-oka/papers/2000/qrsw/qrsw.html

Phillips, F. \& Kim, N., 1996, 'Implications of Chaos Research for New Product Forecasting', Technological forecasting and Social Change 53(3), 239-261. http:// dx.doi.org/10.1016/S0040-1625(96)00090-X

Priesmeyer, H.R., 1992, Organizations and Chaos: Defining the Methods of Nonlinear Management, Quorum Books, Westport.

Ranjan, P., Kumara, S., Surana, A., Manikonda, V., Greaves, M. \& Peng, W., 2002, ‘Decision Making in Logistics: A Chaos Theory Based Analysis', Conference proceedings of AAAI Workshop on Decision Making, March, Stanford, California, viewed 14 January 2011, from http://pdfcast.org/pdf/decision-making-in-logistics-a-chaos-theory2011, from http:
based-analysis.

Rasmussen, D.R. \& Mosekilde, E., 1988, 'Bifurcations and chaos in a generic management model', European Journal of Operations Research 35, 80-88. http://dx.doi.org/ model', European Journal of Op
10.1016/0377-2217(88)90380-3

Roberts, J.H., 2000, 'Developing New Rules for New Markets', Journal of the Academy of Marketing Science 28(1), 31-45. http://dx.doi.org/10.1177/0092070300281004

Rudestam, K.E. \& Newton, R.R., 1992, Surviving Your Dissertation: A Comprehensive Guide to Content and Process, Sage, Newbury Park.

Schiller, Z., Burns, G. \& Miller, K.L., 1996, 'Make It Simple: That's P \& G's new marketing mantra - and it's spreading', Business Week 9, September, 96-104.

Sellito, M.A., Borchardt, M., Pereira, G.M. \& Guimaraes, M.G., 2010, 'Relative complexity measurement of a supply chain based on information theory', Proceedings of the International Multi-Conference on Complexity, Informatics and Cybernetics (IMCIC 2010), International Institute of Informatics and Systemics, Orlando, USA.

Stacey, R.D., 1995, 'The science of complexity: An alternative perspective for strategic change processes', Strategic Management Journal 16, 477-495. http://dx.doi. org/10.1002/smj.4250160606

Stacey, R.D., 1996, Strategic Management and Organisational Dynamics, 2nd edn., Pitman, London.

Stapleton, D., Hanna, J.B. \& Ross, J.R., 2006, 'Enhancing supply chain solutions with the application of chaos theory', Supply Chain Management: An International Journal 11(2), 108-114. http://dx.doi.org/10.1108/13598540610652483

Tapscott, D., 2000, 'Minds over Matter', Business 2.0, Supplement to Intelligence May, 20-24.

Tarokh, M.J., Dabiri, N., Shokouthi, A.H. \& Shafiei, H., 2011, 'The effect of supply network configuration on occurring chaotic behavior in the retailer's inventory', Journal of Industrial Engineering International 7(14), 19-28.

Wang, J., 2008, 'Marketing Channel Sustainable Development on Self-organization', International Journal of Business and Management3(8), 157-162.

Wheatley, M.J., 1996, 'The Unplanned Organization', Noetic Sciences Review, Spring, $16-23$.

Whiting, R., 2001, 'Behaviour Change For Supply Chains - Companies turn to complexity theory to improve business processes', Information Week 831, 56.

Wilding, R., 1998, 'The supply chain complexity triangle: Uncertainty generation in the supply chain', International journal of Physical Distribution and Logistics Management 28(8), 599-616. http://dx.doi.org/10.1108/09600039810247524

Wilkinson, I.F. \& Young, L.C., 2013, 'The past and the future of business marketing theory', Industrial Marketing Management 42, 394-404. http://dx.doi.org/10.1016/ j.indmarman.2013.02.007

Williams, M., 1994, Interactive Marketing: How to use integrated offer-driven advertising, data-base marketing and sales promotion to create maximum action, Prentice Hall, Sydney.

Windt, K. \& Hülsmann, M., 2007, 'Changing Paradigms in Logistics - Understanding the Shift from Conventional Control to Autonomous Cooperation and Control', in M. Hülsmann \& K. Windt (eds.), 2007, Understanding Autonomous Cooperation and Control - The Impact of Autonomy on Management, Information, Communication and Material Flow, Springer, Berlin, pp. 4-16.

Wu, Y. \& Zhang, D.Z., 2007, 'Demand fluctuation and chaotic behaviour by interaction between customers and suppliers', International Journal of Production Economics 107, 250-259. http://dx.doi.org/10.1016/j.ijpe.2006.09.004

Yin, R.K., 2003, Case Study Research-Design and Methods, 3rd edn., Sage, Beverley Hills. 